\title{
EFFECT OF UREA FERTILIZER AND MAIZE COB ASH ON SOIL CHEMICAL PROPERTIES, GROWTH, YIELD, AND MINERAL COMPOSITION OF OKRA, ABELMOSCHUS ESCULENTUS (L.) MOENCH
}

\author{
Aruna Olasekan ADEKIYA*, Christopher Muyiwa ABOYEJI, Oluwagbenga DUNSIN, \\ Ojo Vincent ADEBIYI, Oreoluwa Titilope OYINLOLA \\ Crop and Soil Sciences Dept., Landmark University, Omu-Aran \\ Omu-Aran, Nigeria
}

Received: December 2017; Accepted: May 2018

\begin{abstract}
Field experiments were carried out at the Teaching and Research Farm, Landmark University, OmuAran, Kwara State, Nigeria, in the cropping seasons of 2015 and 2016. The soil at the site of the experiment is an Alfisol classified as an Oxichaplustalf or a Luvisol. The trial consisted of sole and combined applications of urea fertilizer (U) applied at 0,60 , and $120 \mathrm{~kg} \cdot \mathrm{ha}^{-1}$ and maize cob ash (M) applied at 0,3 , and $6 \mathrm{t} \cdot \mathrm{ha}^{-1}$. The results showed that $\mathrm{U}$ and $\mathrm{M}$ alone or in combinations increased the soil chemical properties, growth, yield, and mineral composition of okra compared with the control. $\mathrm{M}$ alone at $3 \mathrm{t} \cdot \mathrm{ha}^{-1}$ produced optimum soil chemical properties, yield, and mineral composition of okra fruit. U alone at $60 \mathrm{~kg} \cdot \mathrm{ha}^{-1} \mathrm{pro}^{-}$ duced optimum yield of okra, while growth and mineral composition were increased when urea fertilizer was applied at $120 \mathrm{~kg} \cdot \mathrm{ha}^{-1}$. The treatment with $\mathrm{U}$ applied at $60 \mathrm{~kg} \cdot \mathrm{ha}^{-1}$ in combination with $\mathrm{M}$ applied at $3 \mathrm{t} \cdot \mathrm{ha}^{-1}\left(\mathrm{U}_{60} \mathrm{M}_{3}\right)$ produced the highest values of okra yield, while $\mathrm{U}$ applied at $120 \mathrm{~kg} \cdot \mathrm{ha}^{-1}$ in combination with $\mathrm{M}$ applied at $3 \mathrm{t} \cdot \mathrm{ha}^{-1}\left(\mathrm{U}_{120} \mathrm{M}_{3}\right)$ has the highest growth and highest $\mathrm{N}, \mathrm{K}, \mathrm{Ca}, \mathrm{Cu}$, and $\mathrm{Fe}$ contents of okra fruit. Compared with the control and using the mean of the two years, $\mathrm{U}_{60} \mathrm{M}_{3}$ increased okra fruit yield by $93.3 \%$. Therefore, for viable production of okra in low nutrient soil of the Nigeria derived savanna or similar soils elsewhere, $60 \mathrm{~kg} \cdot \mathrm{ha}^{-1} \mathrm{U}+3 \mathrm{t} \cdot \mathrm{ha}^{-1} \mathrm{M}\left(\mathrm{U}_{60} \mathrm{M}_{3}\right)$ is recommended. However, for improved mineral quality of okra, $120 \mathrm{~kg} \cdot \mathrm{ha}^{-1} \mathrm{U}+3 \mathrm{t} \cdot \mathrm{ha}^{-1} \mathrm{M}\left(\mathrm{U}_{120} \mathrm{M}_{3}\right)$ is recommended.
\end{abstract}

Key words: urea fertilizer, maize cob ash, okra yield, okra growth, soil chemical properties, okra mineral composition

\section{INTRODUCTION}

Okra is a vegetable crop that belongs to the genus Abelmoschus, family Malvaceae and has two main species - Abelmoschus esculentus (L.) Moench and Abelmoschus caillei (A. Chev.) Stevels (Siemonsma 1982). Okra originates probably from East Africa and today is widely distributed in the tropics, subtropics, and warmer parts of the temperate region (Echo 2003). It is traditionally grown in Côte d'Ivoire, Ghana, Nigeria, Egypt, Sudan, Togo, Benin, Burkina Faso, Cameroon, Tanzania, Zambia, and Zimbabwe. The economic importance of okra cannot be overemphasized. Okra is a popular health food because of its high fiber, vitamin C, and folate content. Okra has high amount of antioxidants. It is also a good source of calcium and potassium. It contains carbohydrate, proteins, and vitamin $\mathrm{C}$ in large quantities (Adeboye \& Oputa 1996). Some of the problems encountered by okra farmers in Nigeria are the low soil fertility and lack of capital to buy chemical fertilizers for optimum crop productivity. Most African soils are inherently low in organic carbon, slightly acidic, and relatively sandy (Adewole $\&$ Dedeke 2012). Consequently, intensive crop production requires high rate of organic and inorganic fertilizers. As a result, the use of organic-based fertilizer has found favor in boosting crop production 
in Nigeria, because it is cheap and less likely to pollute the ground water compared with chemical fertilizer. It improves soil fertility status and enhanced yield. However, the quantities of the organic amendments available may not be sufficient for large-scale okra production. Integrated use of chemical fertilizers and organic material may be a good approach for sustainable production of crops (Agbede \& Adekiya 2012). Corn ash from the combustion of maize cobs, especially after ginning, can be used as a fertilizing and liming material. Different woody ash improved soil and plant nutrition and increased the yield of crops (Abdulhamid \& Mustapha 2009; Owolabi et al. 2003; Odedina et al. 2003; Awodun et al. 2007; Ewulo et al. 2009). However, its combined use with chemical fertilizer has not received research attention. Moreover, the effects of the integrated application of maize cob ash and urea fertilizer on the soil chemical properties, growth, yield, and mineral composition of okra have not been investigated; therefore, the objectives of this study are (1) to determine the effects of sole and integrated application of urea fertilizer and maize cob ash on soil chemical properties, (2) to determine the effects of sole and integrated application of urea fertilizer and maize cob ash on growth and yield of okra, and (3) to determine the effects of sole and integrated application of urea fertilizer and maize cob ash on mineral compositions of okra.

\section{MATERIALS AND METHODS}

Field experiments were carried out at the Teaching and Research Farm, Landmark University, Omu-Aran, Kwara State, Nigeria, in the cropping seasons of 2015 and 2016. Experimental field lies between Latitude $8^{\circ} 9^{\prime} \mathrm{N}$ and Longitude $5^{\circ} 61^{\prime} \mathrm{E}$ and is located in the derived savanna ecological zone of Nigeria. The rainfall pattern was bimodal, with peaks in June and October. The soil at the site of the experiment is an Alfisol classified as an Oxichaplustalf or Luvisol. The mean annual rainfall in the area is about $1300 \mathrm{~mm}$, and the mean annual temperature is $32{ }^{\circ} \mathrm{C}$.

The trial consisted of sole and combined applications of maize cob ash (M) applied at 0,3 , and $6 \mathrm{t} \cdot \mathrm{ha}^{-1}$ and urea fertilizer (U) applied at 0,60 , and
$120 \mathrm{~kg} \cdot \mathrm{ha}^{-1}$. The nine treatments were laid out in randomized complete block design with three replications. The following treatments were evaluated: (1) Control, no urea fertilizer or maize cob ash $\left(\mathrm{U}_{0} \mathrm{M}_{0}\right)$; (2) no urea fertilizer $+3 \mathrm{t} \cdot \mathrm{ha}^{-1} \mathrm{M}\left(\mathrm{U}_{0} \mathrm{M}_{3}\right) ;$; 3 ) no urea fertilizer $+6 \mathrm{t} \cdot \mathrm{ha}^{-1}$ maize cob ash $\left(\mathrm{U}_{0} \mathrm{M}_{6}\right)$; (4) $60 \mathrm{~kg} \cdot \mathrm{ha}^{-1}$ urea fertilizer + no maize cob ash $\left(\mathrm{U}_{60} \mathrm{M}_{0}\right)$; (5) $60 \mathrm{~kg} \cdot \mathrm{ha}^{-1}$ urea fertilizer $+3 \mathrm{t} \cdot \mathrm{ha}^{-1}$ maize cob ash $\left(\mathrm{U}_{60} \mathrm{M}_{3}\right)$; (6) $60 \mathrm{~kg}$ urea fertilizer + $6 \mathrm{t} \cdot \mathrm{ha}^{-1}$ maize cob ash $\left(\mathrm{U}_{60} \mathrm{M}_{6}\right)$; (7) $120 \mathrm{~kg} \cdot \mathrm{ha}^{-1}$ urea fertilizer + no maize cob ash $\left(\mathrm{U}_{120} \mathrm{M}_{0}\right)$; (8) $120 \mathrm{~kg} \cdot \mathrm{ha}^{-1}$ urea fertilizer $+3 \mathrm{t} \cdot \mathrm{ha}^{-1}$ maize cob ash $\left(\mathrm{U}_{120} \mathrm{M}_{3}\right)$; (9) $120 \mathrm{~kg} \cdot \mathrm{ha}^{-1}$ urea fertilizer $+6 \mathrm{t} \cdot \mathrm{ha}^{-1}$ maize cob ash $\left(\mathrm{U}_{120} \mathrm{M}_{6}\right)$.

Maize cob ash used for the experiment was prepared by collecting maize cob from maize farmers, sundried, and burnt into ash inside a bin. The ash was then sieved to remove pebbles and unburnt shaft. After land preparation (ploughing and harrowing), the site was then laid out to the required plot size of $3 \mathrm{~m} \times 3 \mathrm{~m}$. Sowing of okra cultivar NHAe-47-4 was done in May for both 2015 and 2016 cropping seasons. Three seeds of okra were sown per hole at interrow spacing of $0.6 \mathrm{~m}$ and intrarow spacing of $0.6 \mathrm{~m}$, giving a plant population of 27.778 plants $\cdot$ ha $^{-1}$. Two weeks after sowing, thinning to one plant per stand was done followed by manual weeding, and maize cob ash and urea fertilizer were applied in ring form to the soil. Manual weeding was done during the planting season, and insect pest control was carried out using cypermethrin containing preparate applied at the rate of $1.0 \mathrm{~kg} \cdot \mathrm{ha}^{-1}$ a.i.

The soil was analyzed before the start of the experiment and at harvest. The soil samples collected were bulked, air dried, and sieved using a 2$\mathrm{mm}$ sieve and analyzed for particle size; soil organic matter; N, P, K, Ca, and Mg contents; and $\mathrm{pH}$. Soil samples at harvest were collected from 0 to $0.15 \mathrm{~m}$ depth in 2015 and 2016 on an individual plot basis and similarly analyzed for chemical properties as described by Carter (1993). Particle size was determined by the hydrometer method (Gee \& Or 2002). Soil organic carbon was determined by the procedure of Walkley and Black using the dichromate wet oxidation method (Nelson \& Sommers 1996). Organic matter $(\mathrm{OM})$ was calculated by multiplying $\mathrm{C}$ 
by 1.724 . Total $\mathrm{N}$ was determined by the microKjeldahl digestion method (Bremner 1996). Available $\mathrm{P}$ was determined by Bray-1 extraction followed by molybdenum blue colorimetry (Frank et al. 1998). Exchangeable $\mathrm{K}, \mathrm{Ca}$, and $\mathrm{Mg}$ were extracted using $1 \mathrm{M}$ ammonium acetate. Thereafter, $\mathrm{K}$ level was determined on a flame photometer, and $\mathrm{Ca}$ and $\mathrm{Mg}$ were determined by ethylenediaminetetraacetic acid EDTA titration (Hendershot \& Lalande 1993). Heavy metals were determined by using the method of Udo et al. (2009). The Fe, $\mathrm{Cu}, \mathrm{Zn}$, $\mathrm{Cr}$, and $\mathrm{Cd}$ levels were determined by atomic absorption spectrophotometer. Soil $\mathrm{pH}$ was determined using a soil-water medium at a ratio of $1: 2$ with a digital electronic $\mathrm{pH}$ meter.

The sample of about $2 \mathrm{~g}$ of the ash used was analyzed for $\mathrm{N}, \mathrm{P}, \mathrm{K}, \mathrm{Ca}$, and $\mathrm{Mg}$ as described by Tel and Hagarty (1984). N was determined by the micro-Kjeldahl digestion method. Samples were digested with nitric perchloric-sulfuric acid mixture for the determination of $\mathrm{P}, \mathrm{K}, \mathrm{Ca}$, and Mg. Phosphorus was determined colorimetrically using the vanadomolybdate method, $\mathrm{K}$ was determined using a flame photometer, and $\mathrm{Ca}$ and $\mathrm{Mg}$ were determined by the EDTA titration method (Horwitz \& Latimer 2005).

At harvest, 10 okra fruits of uniform sizes were randomly collected from each plot in each year and analyzed for mineral contents. Mineral elements of okra fruits were determined according to the methods recommended by the Association of Official Analytical Chemists (AOAC 2003). N was determined by the micro-Kjeldahl digestion method. One gram of each sample was digested using $12 \mathrm{~cm}^{3}$ of the mixture of $\mathrm{HNO}_{3}, \mathrm{H}_{2} \mathrm{SO}_{4}$, and $\mathrm{HCLO}_{4}(7: 2: 1$ v/v/v). Contents of $\mathrm{Cu}, \mathrm{Fe}, \mathrm{Zn}, \mathrm{K}$, and $\mathrm{Ca}$ were determined by atomic absorption spectrophotometry.

Plant height, number of leaves, and leaf area at mid-flowering stage were determined by using the model $\left\{\mathrm{LA}=0.34(\mathrm{LW})^{1.12}\right\}$ developed by Omolaiye et al. (2015), where $\mathrm{LA}=$ leaf area, $\mathrm{L}=$ leaf length, and $\mathrm{W}=$ leaf width. Pods were harvested at four days interval, counted, and weighed. Pod weight was evaluated based on the cumulative number of pods at eight harvests.

Data collected for okra yield and growth parameters, soil chemical properties, and okra mineral compositions were subjected to analysis of variance (ANOVA) using SPSS 17.0, and means were separated using Duncan's multiple range test (DMRT) at $\mathrm{p}=0.05$ probability level.

\section{RESULTS}

Initial soil fertility status and chemical properties of the amendments used for the experiment

The physicochemical properties of the soil and the maize cob ash are given in Table 1. The soil was sandy loam in texture, high in sand, low in both silt and clay, acidic, and low in organic matter. Total N, available $\mathrm{P}$, and exchangeable $\mathrm{K}, \mathrm{Ca}$, and $\mathrm{Mg}$ according to the critical level of $3.0 \% \mathrm{OM}, 0.20 \% \mathrm{~N}$, $10.0 \mathrm{mg} \cdot \mathrm{kg}^{-1}$ available $\mathrm{P}, 0.16-0.20 \mathrm{cmol} \cdot \mathrm{kg}^{-1} \mathrm{ex}-$ changeable $\mathrm{K}, 2.0 \mathrm{cmol} \cdot \mathrm{kg}^{-1}$ exchangeable $\mathrm{Ca}$, and $0.40 \mathrm{cmol} \cdot \mathrm{kg}^{-1}$ exchangeable $\mathrm{Mg}$ meet the criteria recommended for crop production in ecological zones of Nigeria (Akinrinde \& Obigbesan 2000). The values of heavy metals in the experimental soil before experimentation were all below the permissible limits of $\mathrm{Fe} 100 \mathrm{mg} \cdot \mathrm{kg}^{-1}, \mathrm{Zn} 300 \mathrm{mg} \cdot \mathrm{kg}^{-1}, \mathrm{Cu}$ $100 \mathrm{mg} \cdot \mathrm{kg}^{-1}$, Cr $100 \mathrm{mg} \cdot \mathrm{kg}^{-1}$, and Cd $3 \mathrm{mg} \cdot \mathrm{kg}^{-1}$ by WHO/FAO (Kabata-Pendis \& Mukherjee 2007). The analysis of maize cob ash showed that the $\mathrm{pH}$ was strongly alkaline and it also contained high level of $\mathrm{K}, \mathrm{Ca}$, and $\mathrm{Mg}$ and trace values of $\mathrm{N}$ and $\mathrm{P}$.

Table 1. Soil properties before experimentation and nutrient content of maize cob ash used for the study

\begin{tabular}{lcc}
\hline \multicolumn{1}{c}{ Soil property } & Soil values & $\begin{array}{c}\text { Maize cob } \\
\text { ash values }\end{array}$ \\
\hline Sand (\%) & 76 & \\
Silt $(\%)$ & 13 & \\
Clay $(\%)$ & 11 & \\
Textural class & Sandy loam & \\
pH (water) & 5.25 & 11.3 \\
Organic matter $(\%)$ & 2.04 & \\
Total N $(\%)$ & 0.16 & 0.15 \\
Available P $\left(\mathrm{mg} \cdot \mathrm{kg}^{-1}\right)$ & 6.5 & 0.20 \\
Exchangeable $\mathrm{K}\left(\mathrm{cmol} \cdot \mathrm{kg}^{-1}\right)$ & 0.14 & 5.6 \\
Exchangeable Ca $\left(\mathrm{cmol} \cdot \mathrm{kg}^{-1}\right)$ & 1.8 & 1.8 \\
Exchangeable $\mathrm{Mg}\left(\mathrm{cmol} \cdot \mathrm{kg}^{-1}\right)$ & 0.36 & 3.5 \\
Fe $\left(\mathrm{mg} \cdot \mathrm{kg}^{-1}\right)$ & 7.82 & 12.3 \\
$\mathrm{Zn}\left(\mathrm{mg} \cdot \mathrm{kg}^{-1}\right)$ & 17.2 & 250 \\
$\mathrm{Cr}\left(\mathrm{mg} \cdot \mathrm{kg}^{-1}\right)$ & 0.16 & 10 \\
$\mathrm{Cu}\left(\mathrm{mg} \cdot \mathrm{kg}^{-1}\right)$ & 12.2 & 21 \\
$\mathrm{Cd}\left(\mathrm{mg} \cdot \mathrm{kg}^{-1}\right)$ & 0.01 & 11 \\
\hline
\end{tabular}




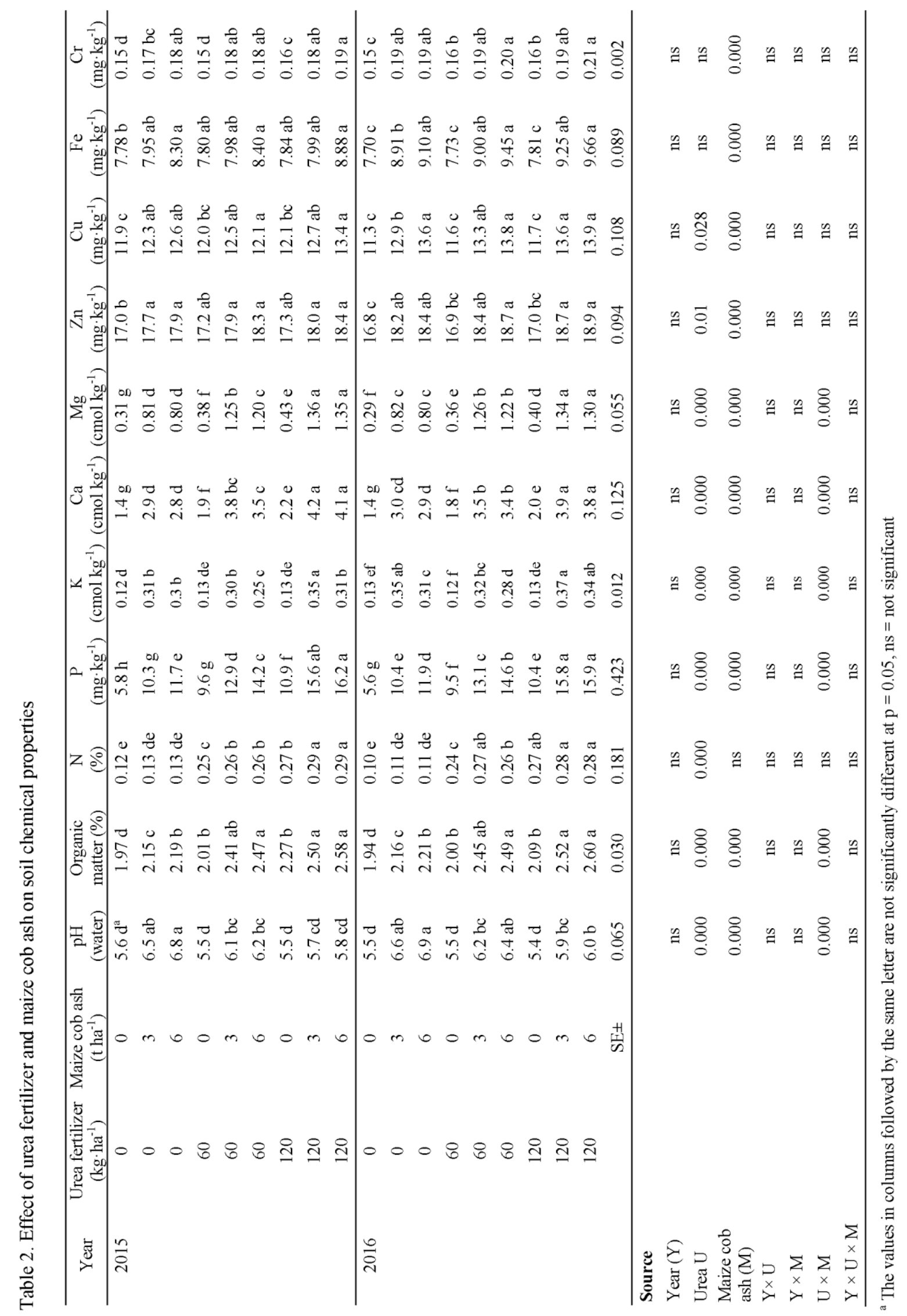


The values of heavy metals ( $\mathrm{Fe}, \mathrm{Zn}, \mathrm{Cr}, \mathrm{Cu}$, and $\mathrm{Cd}$ ) in the maize cob ash were lower than the values reported for wood ash in the literature $-\mathrm{Fe} 19.5 \mathrm{mg} \cdot \mathrm{kg}^{-1}$, $\mathrm{Zn} 700 \mathrm{mg} \cdot \mathrm{kg}^{-1}, \mathrm{Cr} 86 \mathrm{mg} \cdot \mathrm{kg}^{-1}, \mathrm{Cu} 145 \mathrm{mg} \cdot \mathrm{kg}^{-1}$, and $\mathrm{Cd} 21 \mathrm{mg} \cdot \mathrm{kg}^{-1}$ (Etiégni \& Campbell 1991)

Effect of urea fertilizer and maize cob ash on the soil chemical properties

Table 2 shows the effect of urea fertilizer and maize cob ash on soil chemical properties at the end of the experiment in 2015 and 2016. Year (Y) as an individual factor did not influence soil chemical properties. Urea fertilizer $(\mathrm{U})$ alone increased the amounts of soil elements, except $\mathrm{K}, \mathrm{Zn}, \mathrm{Cu}, \mathrm{Fe}$ and $\mathrm{Cr}$, and the increase in $\mathrm{N}, \mathrm{P}, \mathrm{Ca}$ and $\mathrm{Mg}$ contents of the soil in comparison with the not fertilized control. There were no significant differences in $\mathrm{pH}$ but organic matter contents increased due to 60 and $120 \mathrm{~kg} \cdot \mathrm{ha}^{-1}$ urea application as a sole. Maize cob ash (M) alone increased the soil $\mathrm{pH}$, organic matter, and $\mathrm{P}, \mathrm{K}, \mathrm{Ca}, \mathrm{Mg}$,
$\mathrm{Zn}, \mathrm{Cu}, \mathrm{Fe}$, and $\mathrm{Cr}$ levels of the soil significantly. In all treatments in which maize cob ash alone or combined with urea fertilizer were applied, there were no significant differences between maize cob doses, with some little exceptions. The interactive effects of $Y \times$ $\mathrm{U}$ and $\mathrm{Y} \times \mathrm{M}$ were not significant. Combining urea fertilizer with maize cob ash $(U \times M)$, urea fertilizer applied at $120 \mathrm{~kg} \cdot \mathrm{ha}^{-1}+$ maize cob ash applied at $3 \mathrm{t} \cdot \mathrm{ha}^{-1}\left(\mathrm{U}_{120} \mathrm{M}_{3}\right)$, has significantly increased the values of $\mathrm{N}, \mathrm{K}, \mathrm{Ca}$, and $\mathrm{Mg}$. The values of these nutrients at $\mathrm{U}_{120} \mathrm{M}_{3}$ were not significantly different from that of urea fertilizer applied at $120 \mathrm{~kg} \cdot \mathrm{ha}^{-1}+$ maize cob ash applied at $6 \mathrm{t} \cdot \mathrm{ha}^{-1}\left(\mathrm{U}_{120} \mathrm{M}_{6}\right)$. Urea fertilizer applied at $120 \mathrm{~kg} \cdot \mathrm{ha}^{-1}+$ maize cob ash applied at $6 \mathrm{t} \cdot \mathrm{ha}^{-1}$ $\left(\mathrm{U}_{120} \mathrm{M}_{6}\right)$ has the highest values of $\mathrm{pH}$, organic matter, and $\mathrm{P}$, which were also similar to those of $\mathrm{U}_{120} \mathrm{M}_{3}$. However, the values of $\mathrm{Zn}, \mathrm{Cu}, \mathrm{Fe}$, and $\mathrm{Cr}$ were not significant for $(\mathrm{U} \times \mathrm{M})$. Also, $\mathrm{Y} \times \mathrm{U} \times \mathrm{M}$ was not significant for soil chemical properties.

Table 3. Effect of urea fertilizer and maize cob ash on mineral composition of okra fruit

\begin{tabular}{|c|c|c|c|c|c|c|c|}
\hline Year & $\begin{array}{c}\text { Urea ferti- } \\
\text { lizer } \\
\left(\mathrm{kg} \cdot \mathrm{ha}^{-1}\right)\end{array}$ & $\begin{array}{c}\text { Maize cob } \\
\text { ash } \\
\left(\mathrm{t} \mathrm{ha}^{-1}\right)\end{array}$ & $\begin{array}{c}\mathrm{N} \\
(\%)\end{array}$ & $\begin{array}{c}\mathrm{K} \\
(\%)\end{array}$ & $\begin{array}{c}\mathrm{Ca} \\
(\%)\end{array}$ & $\begin{array}{l}\mathrm{Cu} \\
(\%)\end{array}$ & $\begin{array}{l}\mathrm{Fe} \\
(\%)\end{array}$ \\
\hline \multirow[t]{9}{*}{2015} & 0 & 0 & $2.11 \mathrm{f}^{*}$ & $95.4 \mathrm{~h}$ & $88.6 \mathrm{f}$ & $0.31 \mathrm{~g}$ & $7.2 \mathrm{f}$ \\
\hline & 0 & 3 & $2.14 \mathrm{ef}$ & $155.1 \mathrm{de}$ & $140.4 \mathrm{c}$ & $0.75 \mathrm{~cd}$ & $15.2 \mathrm{c}$ \\
\hline & 0 & 6 & $2.15 \mathrm{ef}$ & $150.6 \mathrm{e}$ & $140.1 \mathrm{c}$ & $0.70 \mathrm{~d}$ & $15.1 \mathrm{c}$ \\
\hline & 60 & 0 & $2.54 \mathrm{~d}$ & $110.6 \mathrm{~g}$ & $103.4 \mathrm{e}$ & $0.40 \mathrm{f}$ & $12.9 \mathrm{e}$ \\
\hline & 60 & 3 & $2.95 \mathrm{c}$ & $168.7 \mathrm{bc}$ & $159.6 \mathrm{~b}$ & $0.60 \mathrm{~b}$ & $16.2 \mathrm{~b}$ \\
\hline & 60 & 6 & $2.90 \mathrm{c}$ & $160.4 \mathrm{~cd}$ & $154.8 \mathrm{~b}$ & $0.59 \mathrm{~b}$ & $16.1 \mathrm{~b}$ \\
\hline & 120 & 0 & $3.10 b c$ & $128.5 \mathrm{f}$ & $120.1 \mathrm{~d}$ & $0.51 \mathrm{e}$ & $14.1 \mathrm{~d}$ \\
\hline & 120 & 3 & $3.58 \mathrm{a}$ & $188.1 \mathrm{a}$ & $164.3 \mathrm{a}$ & $0.96 \mathrm{a}$ & $20.8 \mathrm{a}$ \\
\hline & 120 & 6 & $3.50 \mathrm{a}$ & $174.2 \mathrm{ab}$ & $162.7 \mathrm{a}$ & $0.90 \mathrm{a}$ & $20.1 \mathrm{a}$ \\
\hline \multirow[t]{10}{*}{2016} & 0 & 0 & $2.09 \mathrm{f}$ & $90.6 \mathrm{f}$ & $84.4 \mathrm{f}$ & $0.30 \mathrm{~g}$ & $7.1 \mathrm{f}$ \\
\hline & 0 & 3 & $2.13 \mathrm{ef}$ & $154.2 \mathrm{c}$ & $136.6 \mathrm{c}$ & $0.75 \mathrm{bc}$ & $14.9 \mathrm{~d}$ \\
\hline & 0 & 6 & $2.12 \mathrm{ef}$ & $151.0 \mathrm{c}$ & $135.8 \mathrm{c}$ & $0.69 \mathrm{c}$ & $14.8 \mathrm{~d}$ \\
\hline & 60 & 0 & $2.54 \mathrm{~d}$ & $109.1 \mathrm{e}$ & $100.7 \mathrm{e}$ & $0.40 \mathrm{f}$ & 12.4 \\
\hline & 60 & 3 & $2.90 \mathrm{c}$ & $160.7 \mathrm{~b}$ & $154.8 \mathrm{~b}$ & $0.62 \mathrm{~cd}$ & $15.8 \mathrm{c}$ \\
\hline & 60 & 6 & $2.86 \mathrm{c}$ & $158.9 \mathrm{~b}$ & $150.6 \mathrm{~b}$ & $0.60 \mathrm{~d}$ & $15.2 \mathrm{c}$ \\
\hline & 120 & 0 & $3.05 \mathrm{bc}$ & $124.7 \mathrm{~d}$ & $118.1 \mathrm{~d}$ & $0.49 \mathrm{e}$ & $14.1 \mathrm{e}$ \\
\hline & 120 & 3 & $3.47 \mathrm{a}$ & $180.6 \mathrm{a}$ & $164.6 \mathrm{a}$ & $0.92 \mathrm{a}$ & $19.2 \mathrm{a}$ \\
\hline & 120 & 6 & $3.40 \mathrm{a}$ & $172.5 \mathrm{a}$ & $160.4 \mathrm{a}$ & $0.91 \mathrm{a}$ & $18.4 \mathrm{ab}$ \\
\hline & & $\mathrm{SE} \pm$ & 0.066 & 15.440 & 3.580 & 0.027 & 0.489 \\
\hline \multicolumn{8}{|l|}{ Source } \\
\hline \multicolumn{3}{|l|}{ Year $(Y)$} & ns & $\mathrm{ns}$ & $\mathrm{ns}$ & 0.025 & $\mathrm{~ns}$ \\
\hline \multicolumn{3}{|l|}{ Urea U } & 0.000 & $\mathrm{~ns}$ & 0.000 & 0.000 & 0.000 \\
\hline \multicolumn{3}{|c|}{ Maize cob ash (M) } & $\mathrm{ns}$ & 0.025 & 0.000 & 0.000 & 0.000 \\
\hline \multicolumn{3}{|c|}{$\mathrm{Y} \times \mathrm{U}$} & $\mathrm{ns}$ & $\mathrm{ns}$ & $\mathrm{ns}$ & $\mathrm{ns}$ & $\mathrm{ns}$ \\
\hline \multicolumn{3}{|l|}{$\mathrm{Y} \times \mathrm{M}$} & ns & ns & ns & ns & ns \\
\hline \multicolumn{3}{|l|}{$\mathrm{U} \times \mathrm{M}$} & ns & ns & 0.000 & 0.000 & 0.000 \\
\hline \multicolumn{3}{|l|}{$\mathrm{Y} \times \mathrm{U} \times \mathrm{M}$} & ns & ns & $\mathrm{ns}$ & $\mathrm{ns}$ & ns \\
\hline
\end{tabular}

*For explanation see Table 2 


\section{Effect of urea fertilizer and maize cob ash on mineral composition of okra fruit}

The result of the effects of urea fertilizer and maize cob ash on mineral composition of okra fruit are presented in Table 3. Year (Y) as an individual factor did not influence okra mineral composition significantly except $\mathrm{Cu}$. Urea fertilizer (U) increased okra mineral composition significantly, more at $120 \mathrm{~kg} \cdot \mathrm{ha}^{-1}$ urea. With maize cob ash alone (M) $\mathrm{K}, \mathrm{Ca}, \mathrm{Cu}$, and $\mathrm{Fe}$ contents of okra fruit increased significantly compared with the control but there were no difference between maize cob ash doses. The highest increase in the mineral elements in okra fruit were scored at the highest urea and both maize cob ash doses. The interactive effects of $\mathrm{Y} \times \mathrm{U}, \mathrm{Y} \times \mathrm{M}$ and $\mathrm{Y} \times \mathrm{U} \times \mathrm{M}$ were not significant for okra fruit mineral compositions. Using the means of the two years and compared with the control, $\mathrm{U}_{120} \mathrm{M}_{3}$ increased $\mathrm{N}, \mathrm{K}, \mathrm{Ca}$, $\mathrm{Cu}$, and $\mathrm{Fe}$ contents of okra fruit by $68.1 \%, 98.3 \%$, $89.0 \%, 203.2 \%$, and $177.8 \%$, respectively.

Effect of urea fertilizer and maize cob ash on growth parameters and yield of okra fruit

Figures 1-4 show the mean effects of urea fertilizer and maize cob ash on the growth and yield of okra. Maize cob ash alone at 3 and $6 \mathrm{t} \cdot \mathrm{ha}^{-1}$ increased the height of plants, area and number of leaves and fruit yield compared with the control without differences between doses.

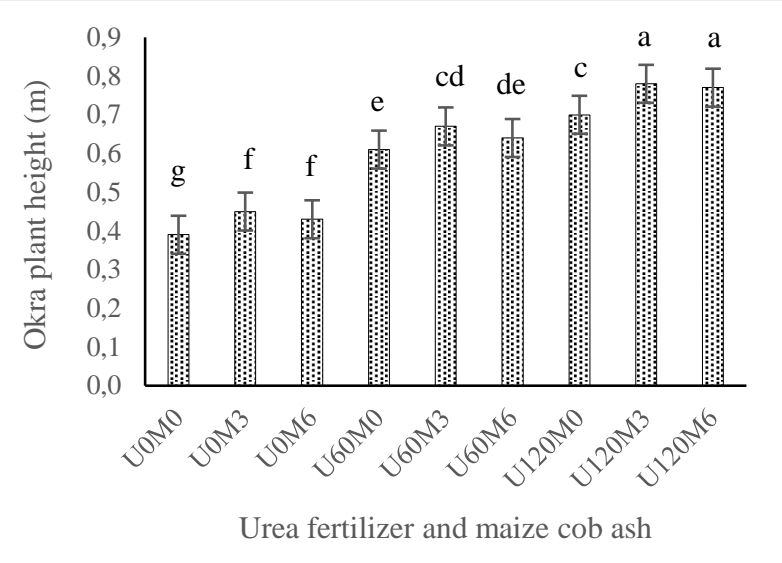

Fig. 1. Influence of urea fertilizer and maize cob ash on the height of okra plants based on the means from two years. $\mathrm{U}=$ Urea fertilizer in $\mathrm{kg} \cdot \mathrm{ha}^{-1} ; \mathrm{M}=$ Maize $\mathrm{cob}$ ash in $\mathrm{t} \cdot \mathrm{ha}^{-1}$; vertical bars show standard errors; bars marked with different letters show means significantly different at 5\% level using Duncan's multiple range test

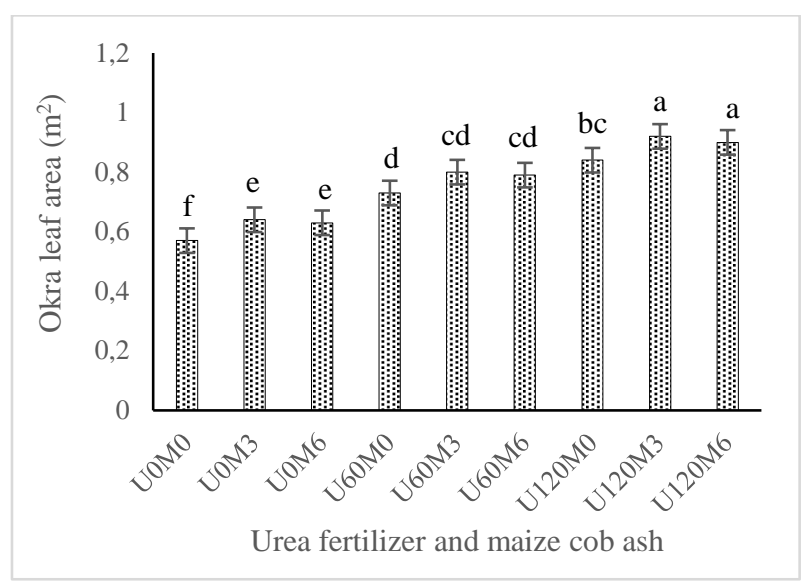

Fig. 2. Influence of urea fertilizer and maize cob ash on okra leaves area based on the means from two years. For explanation see Fig. 1.

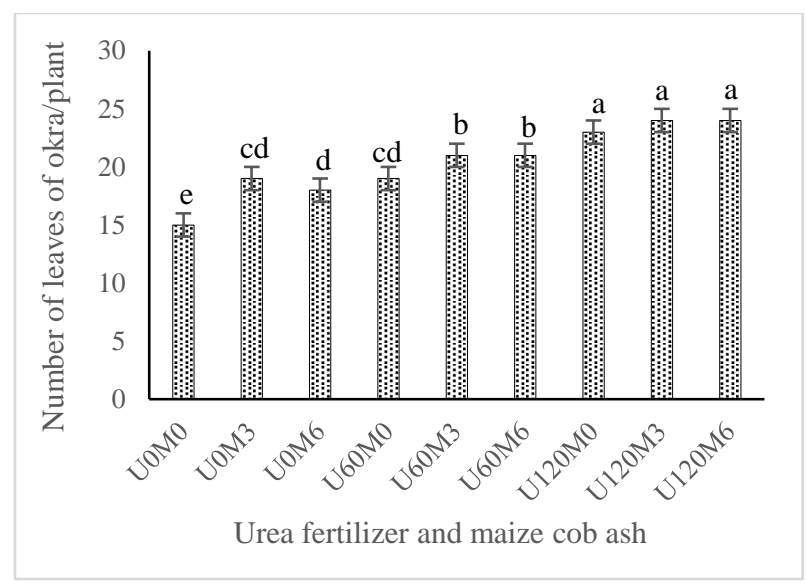

Fig. 3. Influence of urea fertilizer and maize cob ash on okra leaves number based on the means from two years. For explanation see Fig. 1.

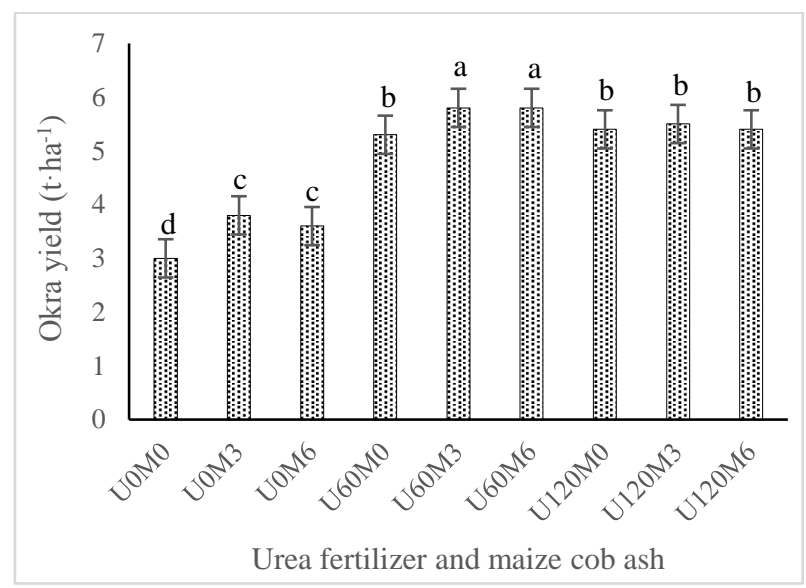

Fig. 4. Influence of urea fertilizer and maize cob ash on okra yield based on the means from two years. For explanation see Fig. 1. 
Using the mean of the two years, it increased the yield, plant height, leaf area, and the number of leaves of okra by $26.7 \%, 15.4 \%, 12.3 \%$, and $26.7 \%$, respectively. Similarly, urea applied alone increased more than cob ash the growth of okra plants. The growth increase depended on the urea dose contrary to the yield, which did not depend on the urea dose. Urea fertilizer applied at $60 \mathrm{~kg} \cdot \mathrm{ha}^{-1}$ in combination with maize cob ash applied at 3 and $6 \mathrm{t} \cdot \mathrm{ha}^{-1}\left(\mathrm{U}_{60} \mathrm{M}_{3}\right.$ and $\mathrm{U}_{60} \mathrm{M}_{6}$ ) caused the highest yield of okra fruit, while urea fertilizer applied at $120 \mathrm{~kg} \cdot \mathrm{ha}^{-1}$ in combination with maize cob ash applied at 3 and $6 \mathrm{t} \cdot \mathrm{ha}$ ${ }^{1}\left(\mathrm{U}_{120} \mathrm{M}_{3}\right.$ and $\left.\mathrm{U}_{120} \mathrm{M}_{6}\right)$ resulted in the highest growth parameters. Compared with the control and using the mean of the two years, $\mathrm{U}_{60} \mathrm{M}_{3}$ increased okra fruit yield by $93.3 \%$.

\section{DISCUSSION}

The fact that maize cob ash or urea fertilizer alone or in combinations increased soil organic matter and $\mathrm{N}, \mathrm{P}, \mathrm{K}, \mathrm{Ca}$, and $\mathrm{Mg}$ contents can be explained by the low initial soil fertility status of the experimental field (Table 1), which confirms the earlier findings (Park et al. 2004; Ewulo et al. 2009; Abdulraheem \& Ojeniyi 2015). Urea fertilizer alone increased soil organic matter and $\mathrm{N}, \mathrm{P}$, $\mathrm{K}, \mathrm{Ca}$, and $\mathrm{Mg}$ relative to the control, probably because of the enhanced microbial activity that led to enhanced production and mineralization of organic matter from natural (native) source in soil (Ewulo et al. 2009). Increased soil organic matter and nutrients caused by urea fertilizer can also be related to the addition of carbon through okra root biomass and crop residues. Maize cob ash improved the basal status of the soil through the increase in soil $\mathrm{pH}$. The calcium oxide content of soil turns into calcium hydroxide in the presence of water. Calcium hydroxide reacts with the carbon dioxide in the air, which results in the formation of calcium carbonate. As a result, wood-ash enhances the lime content of the soil (Steenari et al. 1999). However, urea reduces soil $\mathrm{pH}$ because of its acid producing nature.

The soil nutrient status increased at $3 \mathrm{t} \cdot \mathrm{ha}^{-1}$ maize cob ash and usually did increase with $6 \mathrm{tha}^{-1}$.
The exception was found for $\mathrm{P}$ and $\mathrm{K}$ because their content was higher at the higher dose. The combination of urea and maize cob ash increased $\mathrm{N}$ availability important for microbial action that released of nutrients. In general, the combination of urea fertilizer and maize cob ash increased soil nutrient concentration more than their sole use.

The significant increase in the growth and yield of okra in response to maize cob ash or/and urea fertilizer compared with the control could be adduced to the fact that the soil was low in nutrients. Higher amounts of $\mathrm{N}, \mathrm{P}, \mathrm{K}, \mathrm{Ca}$, and $\mathrm{Mg}$ and higher soil $\mathrm{pH}$ are essential for the growth and yield of okra (Abdulraheem \& Ojeniyi 2015). On an average, yield of $20 \mathrm{t} \cdot \mathrm{ha}^{-1}$ of okra removes from a soil about 60, 25, and $90 \mathrm{~kg}$ of $\mathrm{N}, \mathrm{P}_{2} \mathrm{O}_{5}$, and $\mathrm{K}_{2} \mathrm{O}$ $\mathrm{ha}^{-1}$ (Prabhakar 1996). The result that maize cob ash at $3 \mathrm{t} \cdot \mathrm{ha}^{-1}$ increased the growth and yield of okra most implies that this amount corresponds with other soil factors and okra requirements. Nitrogen strongly stimulates growth through expansion of the crop canopy and better interception of solar radiation (Milford et al. 2000). It also strengths plant roots, enabling plants to take in more water and nutrients, which allows a plant to grow more rapidly (Solangi et al. 2015).

Also the result that growth parameters of okra increased with the increase of urea doses up to $120 \mathrm{~kg} \cdot \mathrm{ha}^{-1}$ while yield was increased with urea dose of $60 \mathrm{~kg} \cdot \mathrm{ha}^{-1}$ can testify that in the experimental condition, the $120 \mathrm{~kg} \cdot \mathrm{ha}^{-1}$ dose was over optimal for yield of fruits. This result agrees with that of Verma et al. (1970) who found that okra fruit production was depressed as $\mathrm{N}$ rate was increased and concluded that fruit yield at this excessive $\mathrm{N}$ rate was declined due to reduction in fruit number per plant. Chauhan and Gupta (1973) cited by Majanbu et al. (1986) reported that dry matter yield in okra significantly increased with $\mathrm{N}$ fertilization but it was not correlated with fruit yield increase. Majanbu et al. (1986) fixed the optimum N requirement for okra production to be $50 \mathrm{~kg} \cdot \mathrm{ha}^{-1}$. From our experiment, it is possible to conclude that $\mathrm{U}_{60} \mathrm{M}_{3}$ was most adequate for the okra production in this soil-climatic zone. 
Table 4. Correlation coefficient between soil chemical properties and mineral composition of okra

\begin{tabular}{llllll}
\hline \multicolumn{7}{c}{ Okra mineral composition } \\
\hline $\begin{array}{c}\text { Soil chemical } \\
\text { property }\end{array}$ & \multicolumn{1}{c}{$\mathrm{N}$} & \multicolumn{1}{c}{$\mathrm{K}$} & \multicolumn{1}{c}{$\mathrm{Ca}$} & \multicolumn{1}{c}{$\mathrm{Cu}$} & \multicolumn{1}{c}{$\mathrm{Fe}$} \\
\hline $\mathrm{pH}$ & $-292(\mathrm{~ns})$ & $0.460(\mathrm{~ns})$ & $0.453(\mathrm{~ns})$ & $0.385(\mathrm{~ns})$ & $0.279(\mathrm{~ns})$ \\
Organic matter & $0.77^{*}(0.015)$ & $0.912^{*}(0.001)$ & $0.940^{*}(0.000)$ & $0.796^{*}(0.010)$ & $0.861^{*}(0.003)$ \\
$\mathrm{N}$ & $0.900^{*}(0.001)$ & $0.783^{*}(0.030)$ & $0.730^{*}(0.042)$ & $0.759^{*}(0.039)$ & $0.746^{*}(0.040)$ \\
$\mathrm{P}$ & $0.839^{*}(0.005)$ & $0.922^{*}(0.000)$ & $0.937^{*}(0.000)$ & $0.840^{*}(0.005)$ & $0.957^{*}(0.000)$ \\
$\mathrm{K}$ & $0.563(\mathrm{~ns})$ & $0.913^{*}(0.001)$ & $0.874^{*}(0.002)$ & $0.903^{*}(0.001)$ & $0.923^{*}(0.000)$ \\
$\mathrm{Ca}$ & $0.707^{*}(0.033)$ & $0.983^{*}(0.000)$ & $0.987^{*}(0.000)$ & $0.886^{*}(0.001)$ & $0.921^{*}(0.000)$ \\
$\mathrm{Mg}$ & $0.677^{*}(0.045)$ & $0.947^{*}(0.000)$ & $0.963^{*}(0.000)$ & $0.818^{*}(0.007)$ & $0.852^{*}(0.004)$ \\
\hline
\end{tabular}

$* \mathrm{p}<0.05$; ns $=$ not significant at $\mathrm{p}<0.05$. Included in brackets are $\mathrm{p}$ values

The application of urea fertilizer and maize cob ash alone or in combination increased $\mathrm{N}, \mathrm{P}, \mathrm{K}$, $\mathrm{Ca}, \mathrm{Cu}$, and $\mathrm{Fe}$ contents in okra fruits compared with the control and is consistent with the soil chemical properties in this experiment; the correlation between soil chemical properties and mineral composition of okra fruit were positive and significant (except for $\mathrm{pH}$ ) (Table 4).

Maize cob ash increased $\mathrm{N}, \mathrm{P}, \mathrm{K}, \mathrm{Ca}, \mathrm{Cu}$, and Fe contents of okra fruits only up to $3 \mathrm{t} \cdot \mathrm{ha}^{-1}$ level. Urea fertilizer applied at $60 \mathrm{~kg} \cdot \mathrm{ha}^{-1}$ in combination with maize cob ash applied at $3 \mathrm{t} \cdot \mathrm{ha}^{-1}\left(\mathrm{U}_{60} \mathrm{M}_{3}\right)$ has the highest $\mathrm{N}, \mathrm{P}, \mathrm{K}, \mathrm{Ca}, \mathrm{Cu}$, and $\mathrm{Fe}$ contents of okra fruits. This was adduced to maximum availability of nutrient especially $\mathrm{N}$ from urea fertilizer and $\mathrm{P}, \mathrm{K}$, $\mathrm{Ca}$, and $\mathrm{Mg}$ from maize cob ash at a balanced proportion.

\section{CONCLUSION}

Urea fertilizer and maize cob ash alone or in combination increased soil chemical properties, growth, yield, and mineral composition of okra compared with the control. Maize cob ash applied alone at $3 \mathrm{t} \cdot \mathrm{ha}^{-1}$ produced optimum soil chemical properties, yield, and mineral composition of okra fruit. Urea fertilizer alone at $60 \mathrm{~kg} \cdot \mathrm{ha}^{-1}$ produced optimum yield of okra while growth and mineral composition was increased at $120 \mathrm{~kg} \cdot \mathrm{ha}^{-1}$ urea fertilizer. Treatment with urea fertilizer applied at $60 \mathrm{~kg} \cdot \mathrm{ha}^{-1}$ in combination with maize cob ash applied at $3 \mathrm{t} \cdot \mathrm{ha}^{-1}$ produced the highest values of okra yield while urea fertilizer applied at $120 \mathrm{~kg} \cdot \mathrm{ha}^{-1}$ in combination with maize cob ash applied at $3 \mathrm{t} \cdot \mathrm{ha}^{-1}$ has the highest $\mathrm{N}$, $\mathrm{K}, \mathrm{Ca}, \mathrm{Cu}$, and $\mathrm{Fe}$ contents of okra fruit. Therefore, for viable production of okra in low nutrient soil of the Nigeria-derived savanna or similar soils elsewhere, $60 \mathrm{~kg} \cdot \mathrm{ha}^{-1}$ urea fertilizer $+3 \mathrm{t} \cdot \mathrm{ha}^{-1}$ maize cob ash is recommended.

\section{REFERENCES}

Abdulhamid N.A., Mustapha S. 2009. Influence of agricultural wood ash on some physico-chemical properties of sandy loam soils at Maiduguri, Nigeria. Journal of League of Researchers in Nigeria 10(1): 84-88.

Abdulraheem M.I., Ojeniyi S.O. 2015. Combined application of urea and sawdust ash in okra production: Effects on yield and nutrients availability. Nigerian Journal of Soil Science 25: 146-154.

Adeboye O.C., Oputa C.O. 1996. Effects of galex on growth and fruit nutrient composition of okra (Abelmoschus esculentus L. Moench). Ife Journal of Agriculture 18(1 \& 2): 1-9.

Adewole M.B., Dedeke O.A. 2012. Growth performance, yield and nutritional quality of Amaranthus cruentus L. under repeated applications of poultry manures. Ife Journal of Science 14(2): 345-355.

Agbede T.M., Adekiya A.O. 2012. Effect of wood ash, poultry manure and NPK fertilizer on soil and leaf nutrient composition, growth and yield of okra (Abelmoschus esculentus). Emirate Journal of Food and Agriculture 24(4): 314-321.

Akinrinde E.A., Obigbesan G.O. 2000. Evaluation of the fertility status of selected soils for crop production in five ecological zones of Nigeria. In: Babalola $\mathrm{O}$. (Ed.), Proceedings of the $26^{\text {th }}$ Annual Conference 
of Soil Science Society of Nigeria. Ibadan, Nigeria, pp. 279-288.

AOAC 2003. Official Methods of Analysis of AOAC International. Arlington, Virginia, USA.

Awodun M.A., Ojeniyi S.O., Adeboye A., Odedina S.A. 2007. Effect of oilpalm bunch refuse ash on soil and plant nutrient composition and yield of maize. American-Eurasian Journal of Sustainable Agriculture 1: 50-54.

Bremner J.M. 1996. Nitrogen-total. In: Sparks D.L. (Ed.), Methods of Soil Analysis, part 3. Chemical Methods. SSSA Book Series 5: 1085-1121. DOI: 10.2136/sssabookser5.3.c37.

Carter M.R. (Ed.). 1993. Soil Sampling and Methods of Analysis. Lewis Publishers, CRC Press, USA.

Chauhan D.S., Gupta M.L. 1973. Effect of nitrogen, phosphorus and potash on growth and development of okra (Abelmoschus esculentus) in sand culture. India Journal of Horticulture 30: 401-405.

ECHO 2003. Plant information sheet, N.F.T. Meyers, USA. http://echonet.com/

Etiégni L., Campbell A.G. 1991. Physical and chemical characteristics of wood ash. Bioresource Technology 37: 173-178. DOI: 10.1016/0960-8524(91)90207-z.

Ewulo B.S., Babadele O.O., Ojeniyi S.O. 2009. Sawdust ash and urea effect on soil and plant nutrient contents and yield of tomato. American-Eurasian Journal of Sustainable Agriculture 3(1): 88-92.

Frank K., Beegle D., Denning J. 1998. Phosphorus. In: Brown J.R. (Ed.), Recommended chemical soil test procedures for the North Central Region, North Central Regional Research Publication No. 221 (revised). Columbia (MO): Missouri Agriculture Experiment Station p. 21-26.

Gee G.W., Or D. 2002. Particle-size analysis. In: Dane J.H., Topp G.C. (Eds.), Methods of Soil Analysis, part 4. Physical Methods. SSSA Book Series 5: 255-293. DOI: 10.2136/sssabookser5.4.c12.

Hendershot W.H., Lalande H. 1993. Ion exchange and exchangeable cations. In: Carter M.R. (Ed.), Soil Sampling and Methods of Analysis. Lewis Publishers, CRC Press, USA.

Horwitz W., Latimer G.W. (Eds.). 2005. Official Methods of Analysis of AOAC International. Arlington, Virginia, USA.

Kabata-Pendias A., Mukherjee A.B. 2007. Trace Elements from Soil to Human. Springer-Verlag, 550 p. DOI: $10.1007 / 978-3-540-32714-1$.

Majanbu I.S., Ogunlela V.B., Ahmed M.K. 1986. Response of two okra (Abelmoschus esculentus L. Moench) varieties to fertilizers: growth and nutrient concentrations as influenced by nitrogen and phosphorus application. Fertilizer Research 8: 297-306. DOI: $10.1007 / \mathrm{bf01048632.}$

Milford G.F.J., Armstrong M.J., Jarvis P.J., Houghton B.J., Bellett-Travers D.M., Jones J., Leigh R.A. 2000. Effects of potassium fertilizer on the yield, quality and potassium offtake of sugar beet crops grown on soils of different potassium status. Journal of Agricultural Science 135: 1-10. DOI: $10.1017 / \mathrm{s} 0021859699007881$.

Nelson D.W., Sommers L.E. 1996. Total carbon, organic carbon, and organic matter. In: Sparks D.L. (Ed.), Methods of Soil Analysis, part 3. Chemical Methods. SSSA Book Series 5: 961-1010. DOI: 10.2136/sssabookser5.3.c34.

Odedina S.A., Odedina J.N., Ayeni S.O., Arowojolu S.A., Adeyeye S.D., Ojeniyi S.O. 2003. Effects of types of Ash on soil fertility, nutrient availability and yield of tomato and pepper. Nigerian Journal of Soil Science 13: 61-67.

Omolaiye J.A., Jayeoba O.J., Akoun J., Ogunbanjo O.R., Adams B.A., Ashidi J.S. 2015. Development of leaf area prediction model of okra (Abelmoschus spp). Production Agriculture and Technology Journal 11(1): 130-136.

Owolabi O., Adeleye A., Oladejo B.T., Ojeniyi S.O. 2003. Effect of wood ash on soil fertility and crop yield in Southwest Nigeria. Nigerian Journal of Soil Science 13: 55-60.

Park B.B., Yanai R.D., Sahm J.M., Ballard B.D., Abrahamson L.P. 2004. Wood ash effects on soil solution and nutrient budgets in a willow bioenergy plantation. Water, Air, and Soil Pollution 159: 209224. DOI: 10.1023/b:wate.0000049177.60761.37.

Prabhakar B.S. 1996. Phosphate and potash use in vegetable crops. Better Crops International 10(2): 16-18.

Solangi M., Suthar V., Wagan B., Siyal A.G., Sarki A., Soothar R.K. 2015. Evaluate the effect of nitrogen and phosphorus fertilizer doses on growth and yield of spinach (Spinacia oleracea L.). Science International (Lahore) 28(1): 379-383.

Siemonsma J.S. 1982. The cultivation of okra (Abelmoschus spp.), a tropical fruit vegetable (with special reference to Ivory Coast). Ph.D. thesis, Wageningen University, the Netherlands, 297 p. [in French with English abstract]

Steenari B-M., Karlsson L.G., Lindqvist O. 1999. Evaluation of the leaching characteristics of wood ash and the influence of ash agglomeration. Biomass and Bioenergy 16: 119-136. DOI: 10.1016/s09619534(98)00070-1. 
Tel D.A., Hagarty M. (Eds.). 1984. Soil and Plant Analysis. International Institute of Tropical Agriculture, Nigeria; University of Guelph, Canada, $277 \mathrm{p}$.

Udo E.J., Ibia T.O., Ogunwale J.A., Ano A.O., Esu I.E. 2009. Manual of Soil, Plant and Water Analyses. Sibon Books, Nigeria, 183 p.
Verma V.K., Pundrik K.K.C., Chauhan K.S. 1970. Effect of different levels of $\mathrm{N}, \mathrm{P}$ and $\mathrm{K}$ on vegetative growth and yield of okra. Punjab Horticultural Journal 10: 130-136. 